\title{
Pituitary carcinoma: a review of the literature
}

\author{
Brian T. Ragel, M.D., and William T. Couldwell, M.D., Ph.D. \\ Department of Neurosurgery, University of Utah, Salt Lake City, Utah
}

\begin{abstract}
Pituitary carcinomas, defined as distant metastases of a pituitary neoplasm, are rare; fewer than 140 reports exist in the English literature. The initial presenting pituitary tumor is usually a secreting, invasive macroadenoma, with adrenocorticotropic hormone (ACTH) - and prolactin (PRL)-secreting tumors being the most common. The latency period between the diagnosis of a pituitary tumor and the diagnosis of a pituitary carcinoma is 9.5 years for ACTHproducing lesions and 4.7 years for PRL-secreting tumors. Survival after documentation of metastatic disease is poor; $66 \%$ of patients die within 1 year. Treatment options include additional surgery, radiotherapy, and chemotherapy, all of which are associated with poor results. Future studies will focus on identifying those invasive pituitary tumors most likely to metastasize and treating them aggressively before they progress to pituitary carcinomas.
\end{abstract}

\section{KEY WORDS • pituitary adenoma • pituitary carcinoma • brain neoplasm • transsphenoidal surgery}

\section{DEFINITION AND INCIDENCE OF PITUITARY CARCINOMAS}

The hallmark of a pituitary carcinoma is distant metastases. ${ }^{78}$ Pituitary tumors grow by expansion and displacement of adjacent structures, with dural invasion noted in $45 \%$ of all cases in one large study. ${ }^{63}$ Nevertheless, histological invasion does not confer the diagnosis of pituitary carcinoma.

Pituitary carcinomas are rare tumors constituting only 0.1 or $0.2 \%$ of pituitary tumors. ${ }^{79,80,83}$ To date, approximately 140 well-documented examples have been reported in the English literature. The vast majority of reported pituitary carcinomas are endocrinologically active (88\%), with $59(42 \%)$ of the reported lesions producing $\mathrm{ACTH}, 1,5$, $6,11,13,17,19,20,22,23,25-27,34,36,37,40,42,43,46-48,53,56,60,64,67,72,77,80,81,87,91,99,100,102$, 107,111,118,121,122 46 (33\%) producing PRL, 3,4,7,9,12,28,30,38,43-45,52,55,59, $69,75,80,82,84-86,89,92,94,96,98,99,103,113,114,116,117,119$ nine $(6 \%)$ producing $\mathrm{GH}, 2,32,35,54,68,70,73,76,106$ seven $(5 \%)$ producing $\mathrm{LH}$ or $\mathrm{FSH},{ }^{8,62}$, $75,83,90,105$ and only one (1\%) producing TSH. ${ }^{65}$ Null-cell pituitary carcinomas represent $17(12 \%)$ of the reported cases. ${ }^{15,16,18,21,29,31,41,49,51,57,58,66,74,80,93,104,108}$ No sex predominance has been reported. ${ }^{80}$ Before the 1970s, PRL levels were not measured and immunohistochemical staining was not performed. ${ }^{26}$ Therefore, a significant number of

Abbreviations used in this paper: $\mathrm{ACTH}=$ adrenocorticotropic hormone; $\mathrm{BrdU}=5$-bromodeoxyuridine; $\mathrm{CNS}=$ central nervous system; FSH = follicle-stimulating hormone; $\mathrm{GH}=$ growth hormone; $\mathrm{LH}=$ luteinizing hormone; $\mathrm{LI}=$ labeling index; $\mathrm{MR}=$ magnetic resonance; $\mathrm{PRL}=$ prolactin; $\mathrm{Rb}=$ retinoblastoma; $\mathrm{TSH}=$ thyroid-stimulating hormone.
PRL-producing carcinomas were probably unrecognized, making data from older literature somewhat unreliable. Sites of pituitary tumor metastasis include the brain, spinal cord, leptomeninges, bone, liver, lymph nodes, ovary, heart, and lung. Of note, systemic spread of the disease is postulated to occur by way of venous circulation to the lungs. Nevertheless, pulmonary sites for the metastasis of pituitary carcinomas are rarely seen. ${ }^{79}$

\section{LATENCY PERIOD AND PATIENT SURVIVAL}

In a series of 15 pituitary carcinomas, the latency period between the presentation of a sellar adenoma and the manifestation of metastasis was approximately half as long in PRL-producing tumors (mean 4.7 years) as in ACTH-producing lesions (mean 9.3-9.5 years) ${ }^{80}$ The overall latency period in cases of pituitary carcinoma has a surprisingly wide range: from a few months to 18 years (median 5 years).$^{80}$ The longest latency interval ( 15.3 years) occurred for patients with Nelson syndrome. ${ }^{80}$ Eighty percent of patients in the series died of metastatic disease between 7 days and 8 years after diagnosis of carcinoma; of these, $66 \%$ died within 1 year. ${ }^{80}$ The mean survival time for the entire study population was approximately 2 years (range $0.25-8$ years), with patients who had craniospinal and systemic metastatic diseases surviving 2.6 years and 1 year, respectively. ${ }^{80}$ Sironi, et al. ${ }^{103}$ reviewed the literature on 33 patients with PRL-secreting carcinomas; all but eight patients died with or as a result of their pituitary carcinoma, with a mean survival time of 2.4 years. 


\section{METASTATIC SPREAD OF THE DISEASE}

Pituitary carcinomas have been reported to metastasize to the cerebral cortex, cerebellum, spinal cord, leptomeninges, cervical lymph nodes, liver, ovaries, and bone. All pituitary carcinomas have displayed a greater tendency toward systemic metastasis than craniospinal metastasis; the rate of systemic metastasis was $71 \%$ for PRL-producing tumors and $57 \%$ for ACTH-producing lesions. ${ }^{80}$ Thirteen percent of tumors have demonstrated both patterns of metastasis. ${ }^{80}$

\section{CLINICAL FEATURES OF PITUITARY CARCINOMAS}

\section{Symptoms and Signs}

Nearly all pituitary carcinomas present as hormone-secreting, invasive macroadenomas with symptoms of mass effect including visual changes, diplopia, and headache. Nonsecreting carcinomas present with mass effect. ${ }^{97}$

\section{Corticotroph Carcinoma}

Most ACTH-producing tumors present with Cushing syndrome; only a few cases of silent corticotroph carcinomas have been reported. ${ }^{79,91}$ Of the seven ACTH-producing adenomas reported in one large series ${ }^{81}$ four occurred in the setting of Nelson syndrome and the serum ACTH levels ranged from 145 to $280,000 \mathrm{pg} / \mathrm{ml}$ (normal level 0-60 pg/ml). Nelson syndrome is the clinical manifestation of an ACTH-secreting adenohypophysial neoplasm that occurs in patients who have undergone adrenalectomy for Cushing syndrome. In its typical form, the syndrome is characterized by the development of an ACTHproducing pituitary tumor with fasting ACTH levels exceeding $200 \mathrm{pmol} / \mathrm{L}$ and hyperpigmentation of the skin. ${ }^{47}$ This secretion of ACTH and related melanotrophic peptides results in hyperpigmentation..$^{47}$ Roncaroli, et al., ${ }^{91}$ reported on patients with clinically silent corticotroph tumors, noting that these pituitary carcinomas presented as invasive macroadenomas with symptoms of mass effect. The outcome for the patients harboring these five tumors was similar to that of patients presenting with Cushing disease. $^{91}$

\section{Prolactin-Secreting Pituitary Carcinomas}

As expected, PRL-producing tumors present with amenorrhea, galactorrhea, or impotence. Initially serum PRL levels can range from 6 to $22,000 \mathrm{ng} / \mathrm{ml}$, with increasing serum levels noted in the presence of tumor recurrence and metastasis..$^{80,119}$

\section{Gonadotroph Carcinomas}

Gonadotroph tumors comprise approximately $30 \%$ of clinically nonfunctioning pituitary tumors and usually present as macroadenomas with suprasellar extension. ${ }^{90}$ In one large series, ${ }^{120}$ only $20 \%$ of these pituitary tumors demonstrated invasion on neuroimaging studies or at the time of the operation. Gonadotroph carcinomas are rare, with only a few published examples. Elevated serum levels of the glycoproteins LH and FSH, and of the $\alpha$-subunit are seen on routine laboratory analysis. The $\alpha$-subunit of glycoprotein hormones, a 92-amino-acid chain, is a component of glycoproteins produced by the adenohypophysis (LH, FSH, and TSH).

\section{Growth Hormone-Secreting Carcinoma}

The GH-secreting pituitary carcinomas present as invasive macroadenomas with acromegaly. Elevated serum levels for $\mathrm{GH}$ and insulin-like growth factor-I have been noted in several cases. ${ }^{32,68}$

\section{IMAGING FINDINGS}

Pituitary carcinomas almost always present as invasive macroadenomas that metastasize both to the CNS and systemically. ${ }^{80}$ For disease of the CNS, MR imaging is the best diagnostic imaging method for defining the extent of the disease. Pituitary carcinomas usually occur in the setting of a known invasive macroadenoma. The intrasellar component is typically displayed as an aggressive pituitary tumor with suprasellar extension and possible invasion of the cavernous sinus. Within the CNS, pituitary carcinomas metastasize to the cerebral lobes, cerebellum, spinal cord, leptomeninges, and subarachnoid space. Interestingly, dural sites of metastasis can mimic meningiomas (for example, a homogeneously enhancing dural-based lesion). ${ }^{62}$ Matsuki, et al. ${ }^{61}$ compared the MR imaging characteristics of both primary intrasellar pituitary tumor and metastatic lesions on $\mathrm{T}_{1}$ - and $\mathrm{T}_{2}$-weighted images, noting similar signal intensities. These MR imaging findings reflect the similar vascularity and stroma of the primary pituitary tumor and the metastatic lesion.

Muhr, et al., ${ }^{69}$ used positron emission tomography and dopamine D2-receptor binding to assess tumor amino acid metabolism ( ${ }^{11} \mathrm{C}$-labeled L-methionine) in vivo in a patient with multiple intracranial metastases of a PRLproducing pituitary carcinoma. They demonstrated a high level of dopamine D2-receptor binding and a high amino acid metabolism within the tumor. After institution of bromocriptine injections, repeated PET imaging was performed and demonstrated decreases in tumor D2-receptor binding and amino acid metabolism. These findings correlated with a decrease in circulating serum PRL. This illustrates PET imaging as a possible in vivo tool in tracking patients with aggressive prolactinomas.

Radionuclide scintigraphy performed using indium 111-octreotide can detect active neuroendocrine neoplasias with somatostatin receptors, such as pituitary tumors, islet cell tumors, medullary thyroid carcinomas, pheochromocytomas, carcinoids, and paragangliomas. ${ }^{32,122} \mathrm{Oc}-$ treotide is an eight-chain amino acid analog of somatostatin that, when combined with a radioactive isotope, is used for radionuclide scintigraphy. This novel imaging examination allows for the identification of distant pituitary metastasis.

\section{HISTOPATHOLOGY OF PITUITARY CARCINOMAS}

\section{Histological Analysis}

The histological and cytological characteristics of pituitary carcinomas vary from bland and monotonous to 


\section{Pituitary carcinoma}

frankly malignant. ${ }^{79}$ Fifty percent of primary tumors and the majority of metastases display nuclear pleomorphism and/or hyperchromasia. ${ }^{79}$ An increased number of mitotic figures are seen in pituitary carcinomas (Fig. 1);26,80 however, the mitotic index for all pituitary tumors (such as pituitary adenomas, invasive adenomas, and pituitary carcinomas) is low with a mean mitotic index of only $0.016 \% .^{79}$ Therefore, mitotic figures do not necessarily provide an indication of a tumor's invasive potential. Histologically, features of frank pituitary malignancy appear suspicious for a metastatic disease from a systemic organ, with breast being the most common. ${ }^{24}$ Immunohistochemically these tumors exhibit staining patterns similar to that of the primary intrasellar adenoma. In general, as pituitary tumors become more aggressive they exhibit a trend for increased microvascular density and increased MIB-1 (Ki-67) and p53 staining (Fig. 2).

\section{Microvascular Density}

Vidal, et al., ${ }^{115}$ evaluated microvascular density in 157 pituitary tumors and seven pituitary carcinomas by using the vascular endothelial marker CD-34 antigen. This study showed a trend toward increased vascularity with more invasive tumors, but the trend did not reach statistical sig- nificance. No correlation was found between the MIB-1 LI and microvessel density.

\section{Immunohistochemical Analysis}

Typical antibodies used to recognize pituitary hormones include those to ACTH, PRL, GH, FSH, LH, TSH, and the $\alpha$-subunit of the glycoprotein hormones (LH, FSH, and TSH). Other markers aiding in the diagnosis of pituitary origin tumors are cytokeratin, epithelial membrane antigen, glial fibrillary acidic protein, and chromogranin A.

\section{Electron Microscopy}

An ultrastructural study of 11 pituitary carcinomas showed that metastatic lesions maintain some of their basic ultrastructural markers. ${ }^{95}$ Ultrastructural investigation of pituitary carcinomas confirms their endocrine nature and, in most but not all cases, reveals their functional differentiation. In most cases, significant cellular atypia and mitotic activity were observed. A unique feature in two ACTH-producing carcinomas was the variable admixture of a smooth endoplasmic reticulum with intermediate (cytokeratin) filaments. In two cases, both involving PRLproducing carcinomas, the cell type comprising the tumor
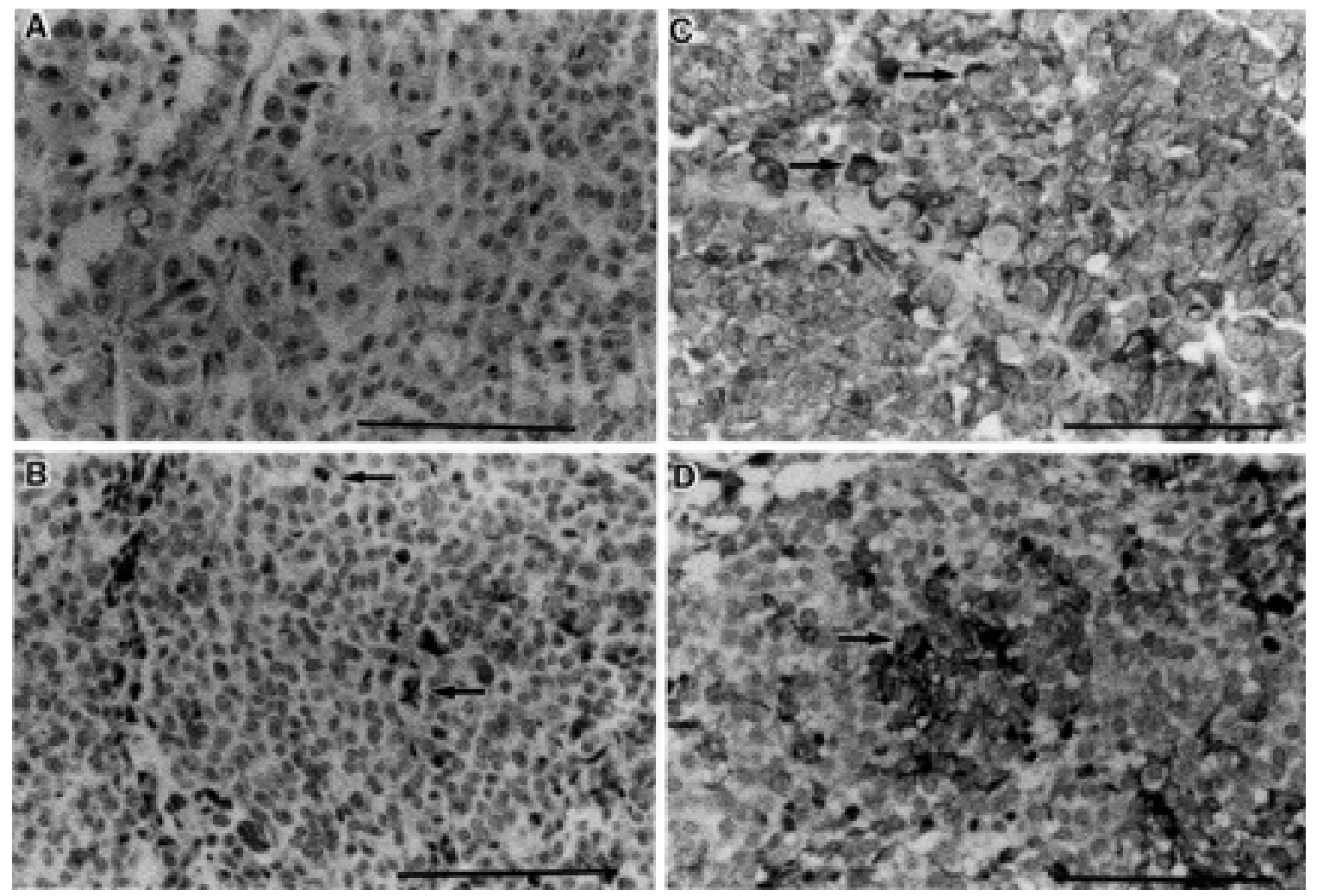

Fig. 1. Comparison of the histological and immunohistochemical features of an ACTH-secreting pituitary tumor and its metastasis to the liver (carcinoma). A: Pituitary tumor composed of uniform cells with abundant cytoplasm. Mitotic figures are not observed. B: Pituitary carcinoma composed of densely packed cells with a high mitotic rate (arrows). C: Tumor showing peripheral cytoplasmic staining for ACTH (arrows). D: The ACTH immunoreactivity in the carcinoma was limited to only a few cells (arrows). H \& E (A and B) and immunoperoxidese staining for ACTH (C and D); original magnification, $\times 350$ (bars $=100 \mu \mathrm{M})$. Reprinted from Cancer Letters, Volume 126, Hinton DR, Hahn JA, Weiss MH, et al., Loss of Rb expression in an ACTH-secreting pituitary carcinoma, pp 209-214, copyright 1998, with permission from Elsevier. 
B. T. Ragel and W. T. Couldwell

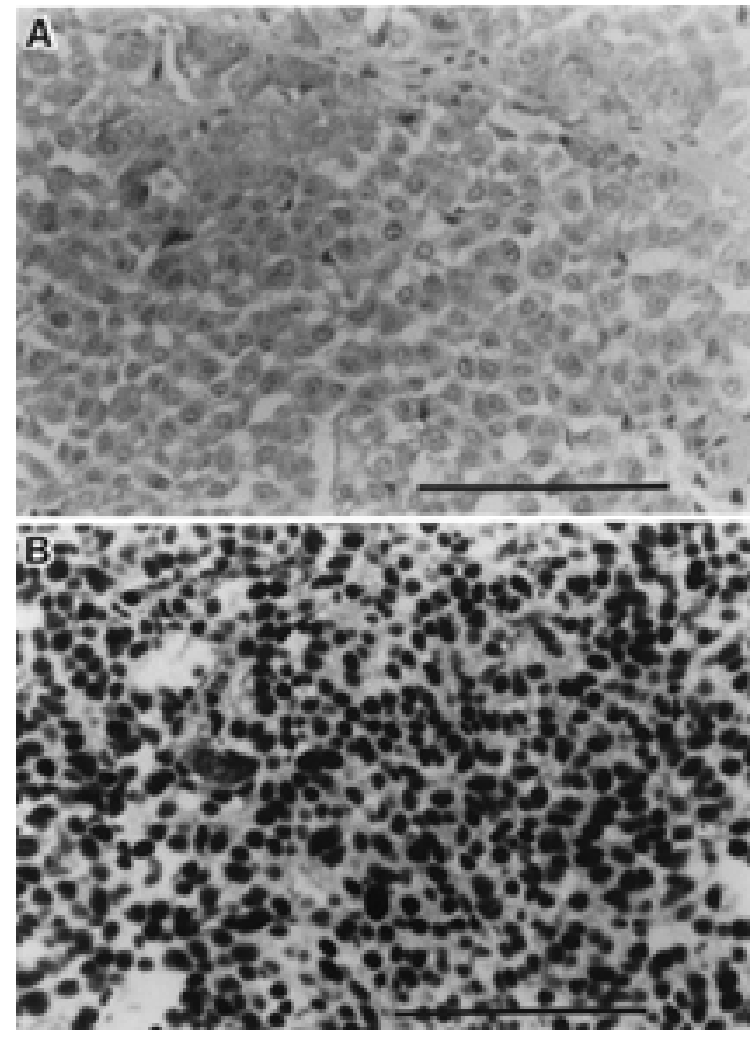

Fig. 2. Expression of p53 in an ACTH-secreting pituitary tumor and a carcinoma. A: Pituitary tumor showing no p53 immunoreactivity. B: Pituitary carcinoma showing strong nuclear p53 immunoreactivity in almost all tumor cells. Immunohistochemical staining for p53, original magnification $\times 350$, (bars $=100 \mu \mathrm{M})$. Reprinted from Cancer Letters, Volume 126, Hinton DR, Hahn JA, Weiss MH, et al., Loss of Rb expression in an ACTH-secreting pituitary carcinoma, pp 209-214, copyright 1998, with permission from Elsevier.

could not be identified on an ultrastructural basis alone. Indeed, the distinction between pituitary adenomas and carcinomas cannot be made on ultrastructural analysis alone..$^{95}$

\section{PROLIFERATIVE MARKERS}

Pituitary carcinomas show an increased mitotic LI, compared with that of the intrasellar pituitary tumor. These mitotic LIs include both the MIB-1 LI and the BrdU LI (Table 1).

\section{The MIB-1 (Ki-67) LI}

Expression of the Ki-67 antigen occurs during the S, M, and $\mathrm{G}_{1}$ phases of the cell cycle and is demonstrated using the MIB-1 antibody. The resulting LI quantifies the proportion of mitotically active cells. Shibuya, et al., ${ }^{101}$ stained 65 pituitary masses, revealing that primary pituitary tumors had a lower amount of Ki-67 (0.8\%) when compared with recurrent tumors $(3.6 \%, \mathrm{p}<0.005)$. In pituitary tumors MIB-1 labeling has produced consistently higher MIB-1 LIs in higher-grade tumors. The MIB-1 LIs
TABLE 1

Comparison of histological and immunohistochemical LIs that aid in differentiating noninvasive pituitary adenomas, invasive pituitary adenomas, and pituitary carcinomas*

\begin{tabular}{ccccc}
\hline \hline $\begin{array}{c}\text { Grade of } \\
\text { Pituitary Tumor }\end{array}$ & $\begin{array}{c}\text { Mitotic } \\
\text { Figures }\end{array}$ & $\begin{array}{c}\text { MIB-1(Ki-67) } \\
\text { LI (\%) }\end{array}$ & $\begin{array}{c}\text { BrdU LI } \\
(\%)\end{array}$ & $\begin{array}{c}\text { p53 LI } \\
(\%)\end{array}$ \\
\hline noninvasive & - & $0.8^{\dagger}$ & $0.3^{\dagger}$ & $0^{\S}$ \\
adenoma & & $1.37^{\ddagger}$ & & \\
invasive & $2 / 10 \mathrm{hpf}^{\|}$ & $3.6^{\dagger}$ & $1.4^{\dagger}$ & $15.2^{\S}$ \\
adenoma & & $4.66^{\ddagger}$ & & $37.3^{\dagger \dagger}$ \\
& & $1.7^{\dagger \dagger}$ & & $57^{\|}$ \\
carcinoma & \multirow{2}{*}{$6 / 10 \mathrm{hpf}^{\|}$} & $11.91^{\ddagger}$ & - & $100^{\S}$ \\
& & $8^{\dagger \dagger}$ & & $49.9^{\dagger \dagger}$ \\
& & $7.8^{\|}$ & & $88^{\|}$ \\
\hline
\end{tabular}

* The number of mitotic figures per high powered field, the MIB-1 (Ki67) LI, and the BrdU LI give information on the tumor's rate of cellular proliferation. The protooncogene $\mathrm{p} 53$ is present in higher grade tumors. - = not applicable.

Data provided by Shibuya, et al., 1992

* Data provided by Thapar, et al., 1996.

$\S$ Data provided by Thapar, et al., 1996.

\| Data provided by Pernicone, et al., 1997.

** Data provided by McCutcheon, et al., 2000.

${ }^{\dagger \dagger}$ Data provided by Gaffey, et al., 2002.

for invasive tumors range from 1.7 to $4.66 \%$ for invasive adenoma, compared with those for pituitary carcinomas, which range from 7.8 to $11.91 \%$ (Table 1). ${ }^{26,80,109}$

\section{The BrdU LI}

The BrdU LI is used to identify only those cells in the DNA synthesis phase (S phase). The BrdU is administered 1 hour before surgery via an intravenous infusion (200 $\left.\mathrm{mg} / \mathrm{m}^{2}\right){ }^{71}$ Excised tumor specimens are fixed in $70 \%$ ethanol and stained using the indirect peroxidase method in which anti-BrdU monoclonal antibody is used as the first antibody. ${ }^{71}$ This provides a more accurate index of DNA synthesis than Ki-67 labeling, and BrdU labeling typically yields lower values, reflecting its greater specificity. One study of 65 tumors showed a significant difference between the BrdU LI of primary and recurrent tumors $(0.3 \%$ compared with $1.4 \%, \mathrm{p}<0.005) .{ }^{101}$ Nagashima, et al., ${ }^{71}$ performed BrdU labeling on 21 pituitary tumors and found less than a $1 \%$ LI for all except two cases of Nelson syndrome, which exhibited LIs greater than $1 \%$. No statistically significant association has been found between the BrdU LI and clinical findings of malignancy. ${ }^{39,71}$

\section{MOLECULAR PATHOGENESIS AND CYTOGENETICS}

The molecular pathogenesis of pituitary carcinoma and other pituitary tumors is being determined. In particular, the Gsp gene may play an important role in approximately $40 \%$ of GH-producing tumors and the Ras oncogene may play a role in anaplastic progression. The MEN-1 gene, which has been cloned, is associated with familial adenomas. ${ }^{24}$ The importance of the Gsp and MEN-l genes in the evolution of pituitary carcinomas still remains to be elucidated. 


\section{Presence of the p53 Gene}

Immunohistochemical staining studies of p53 gene expression in pituitary carcinomas, as opposed to invasive and noninvasive pituitary tumors, show a marked increase in staining as the pituitary lesion progresses to a pituitary carcinoma (Table 1). ${ }^{110}$ One quantitative immunohistochemical analysis of p53 expression in pituitary tumors demonstrated labeling in $0 \%$ of noninvasive tumors, $15.2 \%$ of invasive tumors, and $100 \%$ of metastatic lesions. ${ }^{110}$ Another study of four ACTH-secreting pituitary carcinomas showed progressively stronger staining of p53 in metastatic lesions, with a mean LI in the metastasis group of $49.9 \%$ compared with $37.3 \%$ in the primary pituitary tumor group. ${ }^{26}$ Kumar, et al. ${ }^{50}$ reported a case of metastatic pituitary tumor in which there was an absence of p53.

Genomic Instability-Gains of Chromosomes 5, 7p, and $14 q$ and Losses of Chromosomes 1p, 3p, 10q, 11q, and 22q

Rickert, et al., ${ }^{87}$ studied four metastatic pituitary carcinomas by using comparative genomic hybridization. Chromosomal gains were found in all four metastatic carcinomas. Overall, metastatic pituitary carcinomas were found to have a mean of 8.3 chromosomal imbalances per tumor (7 gains compared with 1.3 losses): 10 in metastatic PRL-producing carcinoma (7.5 gains compared with 2.5 losses) and 6.5 in metastatic ACTH-producing carcinoma (6.5 gains compared with 0 losses). The most common changes were gains of chromosome $5,7 \mathrm{p}$, and $14 \mathrm{q}$ (in three tumors each). High-level gains were found on $13 q 22$ and $14 q$ (two cases each) and on 1q, 3p, 7, 8, 9p, and $21 \mathrm{q}$ (one case each). Bates, et al., ${ }^{6}$ genetically analyzed a metastatic ACTH-producing pituitary carcinoma and compared it with a previous sellar recurrence from the same patient, finding a loss of heterozygosity at loci on autosomes 1p, 3p, 10q26, 11q13, and 22q12. Genetic analysis of invasive masses and pituitary carcinomas may enable better prediction of those tumors associated with a poor prognosis.

\section{The H-ras Gene Point Mutations}

Pei, et al. ${ }^{78}$ studied the molecular mechanisms of pituitary tumorigenesis by using polymerase chain reaction single-stranded conformational polymorphism with DNA sequencing to identify $H$-ras point mutations. Point mutations of $H$-ras were identified in three distant metastatic pituitary tumors, but not in their respective primary pituitary carcinomas or in six invasive adenomas. Two of the mutations included a guanine-to-cytosine substitution at codon 12 and a guanine-to-adenine substitution at codon 18 , resulting in a glycine-to-arginine and an alanine-tothreonine change at these amino acids, respectively. A third mutation involved a single base-pair (adenine) deletion in codon 3 of $H$-ras, which causes a frame shift, resulting in a termination signal at codon 19. Point mutations of the $H$-ras gene may be important in the formation and/or growth of pituitary metastases. ${ }^{78}$

\section{Loss of Dopamine D-2 Receptors in a Malignant Prolactinoma}

Winkelmann, et al., ${ }^{119}$ studied the presence of D-2 receptors at the messenger RNA and protein level, in a pa- tient whose PRL-producing macroadenoma eventually progressed to a pituitary carcinoma. By comparing tumor specimens obtained at neurosurgical operations with those obtained postmortem, the authors were able to show the presence of the D-2 receptor messenger RNA in all specimens, but the absence of $\mathrm{D}-2$ receptor protein from the metastatic pituitary lesions. This indicates a posttranscriptional mechanism by which malignant pituitary tumors develop a resistance to dopamine. ${ }^{119}$

\section{Telomerase Activity and Cellular Immortality}

The telomerase activity responsible for cellular immortality may participate in the development of human cancers. Telomerase is a multisubunit ribonucleoprotein composed of at least three components: hTERT, hTERC, and TEP1. In a single case of PRL-producing pituitary carcinoma Harada, et al., ${ }^{33}$ showed that the metastatic tumor cells had acquired immortality by demonstrating an increase in telomerase activity and hTERT expression.

\section{Expression and Gene Amplification of HER-2/neu}

The HER-2/neu protein is a protooncogene located on chromosome $17 \mathrm{q}$ that encodes a $185-\mathrm{kD}$ transmembrane tyrosine kinase receptor belonging to the epidermal growth factor receptor family. Studies have demonstrated overexpression of HER-2/neu in pituitary tumors. ${ }^{90}$ Roncaroli, et al., ${ }^{90}$ analyzed two cases of gonadotropic pituitary carcinoma for HER-2/neu with immunohistochemical staining, fluorescence in situ hybridization, and chromogenic in situ hybridization. Results of the HER$2 /$ neu analysis showed low-level amplification in pituitary recurrence and metastasis, indicating an association between HER-2/neu and more aggressive pituitary tumors. ${ }^{90}$

\section{Retinoblastoma Gene}

Involvement of the $R b$ gene has been suggested based on the frequent occurrence of pituitary carcinomas in studies of mice with heterozygous deletions of the $R b$ gene. ${ }^{34,118}$ Hinton, et al., ${ }^{36}$ described a patient with two adjacent but histologically discrete pituitary tumors, one a benign ACTH-positive adenoma and the other an ACTHpositive carcinoma that metastasized. The tumor was found to express the $R b$ gene, but the carcinoma did not, indicating a loss of $R b$ expression in the pathogenesis of pituitary carcinomas. ${ }^{36}$

\section{GENETIC SUSCEPTIBILITY OF PATIENTS}

The $M E N-1$ gene predisposes patients to pituitary tumors; however, this gene does not appear to increase the risk for developing pituitary carcinomas.

\section{CAUSES OF PITUITARY CARCINOMAS AND PREDICTIVE FACTORS}

Several possible causes have been proposed for the pathogenesis of pituitary carcinomas. These hypotheses include the following: 1) consequence of previous irradiation in the treatment of a pituitary tumor; 2) microscopic tumor seeding from a previous pituitary surgery; 3) malignant progression of a pituitary tumor; and 4) de novo car- 
cinoma. Brada, et al., ${ }^{10}$ analyzed 334 patients with pituitary tumors who were treated with surgery and radiotherapy (median dose $45 \mathrm{~Gy}$ ) and observed for a total of 3760 patient years. In five of these patients, a second brain tumor developed: two astrocytomas, two meningiomas, and one meningeal sarcoma. No case of malignant transformation of the pituitary tumor was reported. Tumor seeding from opening of the subarachnoid space during previous pituitary surgery has been suggested, but no definitive correlation has yet been made..$^{56,114}$ Many authors favor a progression of an adenoma-to-carcinoma sequence, based on their laboratory observations of similar histological findings, molecular markers, and result of a loss-of-heterozygosity analysis between pituitary tumors and metastases. ${ }^{26,80,121,122}$ Nevertheless, in a recent case report the authors described a genetic analysis in which the primary and metastatic pituitary lesions were distinct clones, ${ }^{122}$ indicating either a de novo pituitary tumorigenesis or a separate clonal expansion from the original tumor. ${ }^{122}$

There are several long-term survivors of pituitary carcinoma; $;^{53,114}$ however, no identifiable factors have been noted to correlate with increased survival.

\section{TREATMENT}

Treatment options for pituitary carcinoma include resection, dopamine agonists (for PRL-producing tumors), somatostatin analogs (for GH-producing tumors), radiotherapy, and chemotherapy. These treatments are palliative only and the mean survival time for these patients ranges from 2 to 2.4 years, ${ }^{80,103}$ although several reports of long-term survivors have been published..$^{53,114}$

\section{Dopamine Agonists}

The dopamine agonists bromocriptine, pergolide, quinagolide, and cabergoline offer only palliation in the treatment of metastatic PRL-producing tumors. ${ }^{119}$ Initially, these agonists induce decreases in serum PRL levels and retard tumor growth. Unfortunately, these pituitary carcinomas will typically "escape" dopamine suppression and PRL levels may rise as high as 20,000 ng/ml (normal PRL levels $4-30 \mathrm{ng} / \mathrm{ml}$ in female patients and $4-23 \mathrm{ng} / \mathrm{ml}$ in male patients). ${ }^{64,79,119}$

\section{Somatostatin Analogs}

The medical approach to patients with GH-secreting or clinically nonfunctioning pituitary tumor has made considerable progress thanks to the use of new somatostatin analogs such as octreotide. ${ }^{14,81}$ These agents were first used to treat acromegaly in the mid-1980s and numerous studies have shown a reduction in $\mathrm{GH}$ concentration in more than $90 \%$ of patients with this disorder. Good results were also obtained using slow-release analog treatment for TSH-secreting tumors, whereas the therapeutic efficacy of these peptides for clinically nonfunctioning tumors remains controversial. Treatment with somatostatin analogs improves the patient's symptoms, normalizes hormone secretion, and in some cases may induce a reduction in the volume of the pituitary tumors. Scintigraphy with octreotide may be useful in selecting patients who respond to this form of treatment. ${ }^{14}$

\section{Radiation Therapy}

Radiation treatment directed to the sella and to distant metastases is a common adjuvant therapy used after pituitary resection. ${ }^{62,80}$ Unfortunately, it does not appear to change disease outcome. ${ }^{62,80}$ The sella and the parasellar region are initially treated by fractionated, limited-field irradiation, with total radiation doses between 45 and 55 Gy. ${ }^{53,62}$ Whole-brain radiation therapy is reserved for intracranial metastasis. Recently, stereotactic radiosurgery (gamma knife surgery) was used in the treatment of a PRL-secreting carcinoma, although no mention of benefit was made in that report. ${ }^{119}$ The radiation regimen used in an ACTH-secreting pituitary carcinoma harbored by a long-term survivor was initial radiotherapy to the sella turcica (56 Gy), followed by whole-brain ${ }^{60} \mathrm{Co}$ radiotherapy (24 Gy) after the discovery of craniospinal metastasis..$^{53}$

\section{Chemotherapy Protocols}

To date, a number of different chemotherapy protocols have been used with disappointing results. ${ }^{62,65,80,121}$ The agents used in these protocols have included carmustine, hydroxyurea, 5-fluorouracil, and dexamethasone (to suppress ACTH-producing tumors); bromocriptine and cabergoline (to suppress PRL-producing tumors); and the St. Bart protocol, consisting of 5-fluorouracil with folinic acid and $\alpha$-interferon (for neuroendocrine tumors). ${ }^{112}$

\section{References}

1. Ahmed M, Kanaan I, Alarifi A, et al: ACTH-producing pituitary cancer: experience at the King Faisal Specialist Hospital \& Research Centre. Pituitary 3:105-112, 2000

2. Asai A, Matsutani M, Funada N, et al: Malignant growth hormone-secreting pituitary adenoma with hematogenous dural metastasis: case report. Neurosurgery 22:1091-1094, 1988

3. Assies J, Verhoeff NP, Bosch DA, et al: Intracranial dissemination of a macroprolactinoma. Clin Endocrinol 38:539-546, 1993

4. Atienza DM, Vigersky RJ, Lack EE, et al: Prolactin-producing pituitary carcinoma with pulmonary metastases. Cancer 68: 1605-1610, 1991

5. Ball SG: Clinical and genetic changes in a case of a Cushing's carcinoma. Clin Endocrinol 44:125-126, 1996

6. Bates AS, Buckley N, Boggild MD, et al: Clinical and genetic changes in a case of a Cushing's carcinoma. Clin Endocrinol 42:663-672, 1995

7. Bayindir C, Balak N, Gazioglu N: Prolactin-secreting carcinoma of the pituitary: clinicopathological and immunohistochemical study of a case with intracranial and intraspinal dissemination. Br J Neurosurg 11:350-355, 1997

8. Beauchesne P, Trouillas J, Barral F, et al: Gonadotropic pituitary carcinoma: case report. Neurosurgery 37:810-816, 1995

9. Berezin M, Gutman I, Tadmor R, et al: Malignant prolactinoma. Acta Endocrinol 127:476-480, 1992

10. Brada M, Ford D, Ashley S, et al: Risk of second brain tumour after conservative surgery and radiotherapy for pituitary adenoma. BMJ 304:1343-1346, 1992

11. Casson IF, Walker BA, Hipkin LJ, et al: An intrasellar pituitary tumour producing metastases in liver, bone and lymph glands and demonstration of ACTH in the metastatic deposits. Acta Endocrinol 111:300-304, 1986

12. Cohen DL, Diengdoh JV, Thomas DG, et al: An intracranial metastasis from a PRL secreting pituitary tumour. Clin Endocrinol 18:259-264, 1983 
13. Cohen H, Dible JH: Pituitary basophilism associated with a basophil carcinoma of the anterior lobe of the pituitary gland. Brain 59:395-407, 1936

14. Colao A, Dorato M, Pulcrano M, et al: [Somatostatin analogs in the clinical management of pituitary neoplasms.] Minerva Endocrinol 26:181-191, 2001 (Itl)

15. Cusimano MD, Ohori P, Martinez AJ, et al: Pituitary carcinoma. Skull Base Surg 4:46-51, 1994

16. D'Abrera VS, Burke WJ, Bleasel KF, et al: Carcinoma of the pituitary gland. J Pathol 109:335-343, 1973

17. Della Casa S, Corsello SM, Satta MA, et al: Intracranial and spinal dissemination of an ACTH secreting pituitary neoplasia. Case report and review of the literature. Ann Endocrinol 58:503-509, 1997

18. Epstein JA, Epstein BS, Molho L, et al: Carcinoma of the pituitary gland with metastases to the spinal cord and roots of the cauda equina. J Neurosurg 21:846-853, 1964

19. Farrell WE, Coll AP, Clayton RN, et al: Corticotroph carcinoma presenting as a silent corticotroph adenoma. Pituitary 6: 41-47, 2003

20. Feiring EH, Davidoff LM, Zimmerman HM: Primary carcinoma of the pituitary. J Neuropathol Exp Neurol 12:205-222, 1953

21. Fleischer AS, Reagan T, Ransohoff J: Primary carcinoma of the pituitary with metastasis to the brain stem. Case report. J Neurosurg 36:781-784, 1972

22. Forbes W: Carcinoma of the pituitary gland with metastases to the liver in a case of Cushing's syndrome. J Pathol Bact 59: 137-144, 1947

23. Frost AR, Tenner S, Tenner M, et al: ACTH-producing pituitary carcinoma presenting as the cauda equina syndrome. Arch Pathol Lab Med 119:93-96, 1995

24. Fuller GN, Goodman JC: Practical Review of Neuropathology. Philadelphia: Lippincott Williams \& Wilkins, 2001

25. Gabrilove JL, Anderson PJ, Halmi NS: Pituitary pro-opiomelanocortin-cell carcinoma occurring in conjunction with a glioblastoma in a patient with Cushing's disease and subsequent Nelson's syndrome. Clin Endocrinol 25:117-126, 1986

26. Gaffey TA, Scheithauer BW, Lloyd RV, et al: Corticotroph carcinoma of the pituitary: a clinicopathological study. Report of four cases. J Neurosurg 96:352-360, 2002

27. Garrao AF, Sobrinho LG, Pedro-Oliveira, et al: ACTH-producing carcinoma of the pituitary with haematogenic metastases. Eur J Endocrinol 137:176-180, 1997

28. Gasser RW, Finkenstedt G, Skrabal F, et al: Multiple intracranial metastases from a prolactin secreting pituitary tumour. Clin Endocrinol 22:17-27, 1985

29. Gilmour MD: Carcinoma of the pituitary gland with abdominal metastases. J Pathol 35:265-269, 1932

30. Gollard R, Kosty M, Cheney C, et al: Prolactin-secreting pituitary carcinoma with implants in the cheek pouch and metastases to the ovaries. A case report and literature review. Cancer 76:1814-1820, 1995

31. Graf CJ, Blinderman EE, Terplan KL: Pituitary carcinoma of the pituitary in a child with distant metastases. J Neurosurg 19:254-259, 1962

32. Greenman Y, Woolf $\mathrm{P}$, Coniglio $\mathrm{J}$, et al: Remission of acromegaly caused by pituitary carcinoma after surgical excision of growth hormone-secreting metastasis detected by 111 indium pentetreotide scan. J Clin Endocrinol Metab 81: 1628-1633, 1996

33. Harada K, Arita K, Kurisu K, et al: Telomerase activity and the expression of telomerase components in pituitary adenoma with malignant transformation. Surg Neurol 53:267-274, 2000

34. Harvey M, Vogel H, Lee EY, et al: Mice deficient in both p53 and $\mathrm{Rb}$ develop tumors primarily of endocrine origin. Cancer Res 55:1146-1151, 1995

35. Hashimoto N, Handa H, Nishi S: Intracranial and intraspinal dissemination from a growth hormone-secreting pituitary tumor. Case report. J Neurosurg 64:140-144, 1986

36. Hinton DR, Hahn JA, Weiss MH, et al: Loss of Rb expression in an ACTH-secreting pituitary carcinoma. Cancer Lett 126: 209-214, 1998

37. Holthouse DJ, Robbins PD, Kahler R, et al: Corticotroph pituitary carcinoma: case report and literature review. Endocr Pathol 12:329-341, 2001

38. Hurel SJ, Harris PE, McNicol AM, et al: Metastatic prolactinoma: effect of octreotide, cabergoline, carboplatin and etoposide; immunocytochemical analysis of proto-oncogene expression. J Clin Endocrinol Metab 82:2962-2965, 1997

39. Ikeda H, Yoshimoto T: The relationship between c-myc protein expression, the bromodeoxyuridine labeling index and the biological behavior of pituitary adenomas. Acta Neuropathol 83:361-364, 1992

40. Imai T, Funahashi H, Tanaka Y, et al: Adrenalectomy for treatment of Cushing syndrome: results in 122 patients and long-term follow-up studies. World J Surg 20:781-787, 1996

41. Jamjoom A, Moss T, Coakham H, et al: Cervical lymph nodes metastases from a pituitary carcinoma. $\mathbf{B r} \mathbf{J}$ Neurosurg 8 : 87-92, 1994

42. Kaiser FE, Orth DN, Mukai K, et al: A pituitary parasellar tumor with extracranial metastases and high, partially suppressible levels of adrenocorticotropin and related peptides. J Clin Endocrinol Metab 57:649-653, 1983

43. Kaltsas GA, Grossman AB: Malignant pituitary tumours. Pituitary 1:69-81, 1998

44. Kamphorst W, Wolbers JG, Ponssen H, et al: Ectopic parasellar pituitary adenoma with subarachnoid seeding. J Neurol Neurosurg Psychiatry 55:73-74, 1992

45. Kasantikul V, Boonjunwetwat D, Suwangool P: Prolactin cell carcinoma of the pituitary. J Med Assoc Thai 76:230-237, 1993

46. Kemink L, Pieters G, Hermus A, et al: Patient's age is a simple predictive factor for the development of Nelson's syndrome after total adrenalectomy for Cushing's disease. J Clin Endocrinol Metab 79:887-889, 1994

47. Kemink SA, Wesseling P, Pieters GF, et al: Progression of a Nelson's adenoma to pituitary carcinoma; a case report and review of the literature. J Endocrinol Invest 22:70-75, 1999

48. Kouhara H, Tatekawa T, Koga M, et al: Intracranial and intraspinal dissemination of an ACTH-secreting pituitary tumor. Endocrinol Jpn 39:177-184, 1992

49. Kumar K, Kelly M: Benign pituitary adenoma with multiple dural metastases: a case report. Surg Neurol 54:380-384, 2000

50. Kumar K, Macaulay RJ, Kelly M, et al: Absent p53 immunohistochemical staining in a pituitary carcinoma. Can J Neurol Sci 28:174-178, 2001

51. Kuroki M, Tanaka R, Yokoyama M, et al: Subarachnoid dissemination of a pituitary adenoma. Surg Neurol 28:71-76, 1987

52. Landgraf R, Rieder G, Schmiedek P, et al: Hormone-active intradural spinal metastasis of a prolactinoma-a case report. Klin Wochenschr 63:379-384, 1985

53. Landman RE, Horwith M, Peterson RE, et al: Long-term survival with ACTH-secreting carcinoma of the pituitary: a case report and review of the literature. J Clin Endocrinol Metab 87:3084-3089, 2002

54. le Roux CW, Mulla A, Meeran K: Pituitary carcinoma as a cause of acromegaly. N Engl J Med 345:1645-1646, 2001

55. Long MA, Colquhoun IR: Case report: multiple intra-cranial metastases from a prolactin-secreting pituitary tumour. Clin Radiol 49:356-358, 1994

56. Lormeau B, Miossec P, Sibony M, et al: Adrenocorticotropinproducing pituitary carcinoma with liver metastasis. J Endocrinol Invest 20:230-236, 1997

57. Luzi P, Miracco C, Lio R, et al: Endocrine inactive pituitary 
carcinoma metastasizing to cervical lymph nodes: a case report. Hum Pathol 18:90-92, 1987

58. Madonick MJ, Rubinstein LJ, Dasco MR, et al: Chromophobe adenoma of pituitary gland with subarachnoid metastases. Neurology 13:836-840, 1963

59. Martin NA, Hales M, Wilson CB: Cerebellar metastasis from a prolactinoma during treatment with bromocriptine. J Neurosurg 55:615-619, 1981

60. Masuda T, Akasaka Y, Ishikawa Y, et al: An ACTH-producing pituitary carcinoma developing Cushing's disease. Pathol Res Pract 195:183-187, 1999

61. Matsuki M, Kaji Y, Matsuo M, et al: MR findings of subarachnoid dissemination of a pituitary adenoma. Br J Radiol 73:783-785, 2000

62. McCutcheon IE, Pieper DR, Fuller GN, et al: Pituitary carcinoma containing gonadotropins: treatment by radical excision and cytotoxic chemotherapy: case report. Neurosurgery 46: 1233-1240, 2000

63. Meij BP, Lopes MB, Ellegala DB, et al: The long-term significance of microscopic dural invasion in 354 patients with pituitary adenomas treated with transsphenoidal surgery. J Neurosurg 96:195-208, 2002

64. Mercado-Asis LB, Yanovski JA, Tracer HL, et al: Acute effects of bromocriptine, cyproheptadine, and valproic acid on plasma adrenocorticotropin secretion in Nelson's syndrome. J Clin Endocrinol Metab 82:514-517, 1997

65. Mixson AJ, Friedman TC, Katz DA, et al: Thyrotropin-secreting pituitary carcinoma. J Clin Endocrinol Metab 76: 529-533, 1993

66. Moberg A: A case of pituitary chromophobe adenoma with metastases in the heart. Acta Pathol Microbiol Scand 45: 243-249, 1959

67. Moore TJ, Dluhy RG, Williams GH, et al: Nelson's syndrome: frequency, prognosis, and effect of prior pituitary irradiation. Ann Intern Med 85:731-734, 1976

68. Mountcastle RB, Roof BS, Mayfield RK, et al: Pituitary adenocarcinoma in an acromegalic patient: response to bromocriptine and pituitary testing: a review of the literature on 36 cases of pituitary carcinoma. Am J Med Sci 298:109-118, 1989

69. Muhr C, Bergstrom M, Lundberg PO, et al: Malignant prolactinoma with multiple intracranial metastases studied with positron emission tomography. Neurosurgery 22:374-379, 1988

70. Myles ST, Johns RD, Curry B: Clinicopathological conference. Carcinoma of the pituitary gland with metastases to bone. Can J Neurol Sci 11:310-317, 1984

71. Nagashima T, Murovic JA, Hoshino T, et al: The proliferative potential of human pituitary tumors in situ. J Neurosurg 64: 588-593, 1986

72. Nawata H, Higuchi K, Ikuyama S, et al: Corticotropin-releasing hormone- and adrenocorticotropin-producing pituitary carcinoma with metastases to the liver and lung in a patient with Cushing's disease. J Clin Endocrinol Metab 71:1068-1073, 1990

73. Newton TH, Burhenne HJ, Palubinskas AJ: Primary carcinoma of the pituitary. AJR 87:110-119, 1962

74. Nudleman KL, Choi B, Kusske JA: Primary pituitary carcinoma: a clinical pathological study. Neurosurgery 16:90-95, 1985

75. O'Brien DP, Phillips JP, Rawluk DR, et al: Intracranial metastases from pituitary adenoma. Br J Neurosurg 9:211-218, 1995

76. Ogilvy KM, Jakubowski J: Intracranial dissemination of pituitary adenomas. J Neurol Neurosurg Psychiatry 36:199-205, 1973

77. Papotti M, Limone P, Riva C, et al: Malignant evolution of an ACTH-producing pituitary tumor treated with intrasellar implantation of $90 \mathrm{Y}$. Case report and review of the literature. Appl Pathol 2:10-21, 1984

78. Pei L, Melmed S, Scheithauer B, et al: H-ras mutations in hu- man pituitary carcinoma metastases. J Clin Endocrinol Metab 78:842-846, 1994

79. Pernicone PJ, Scheithauer BW: Invasive pituitary adenoma and pituitary carcinoma, in Thapar K, Kovacs K, Scheithauer BW, et al (eds): Diagnosis and Management of Pituitary Tumors. Totowa, NJ: Humana Press, 2001, pp 369-386

80. Pernicone PJ, Scheithauer BW, Sebo TJ, et al: Pituitary carcinoma: a clinicopathologic study of 15 cases. Cancer 79: 804-812, 1997

81. Petrini L, Gasperi M, Pilosu R, et al: Long-term treatment of Nelson's syndrome by octreotide: a case report. J Endocrinol Invest 17:135-139, 1994

82. Petrossians P, de Herder W, Kwekkeboom D, et al: Malignant prolactinoma discovered by D2 receptor imaging. J Clin Endocrinol Metab 85:398-401, 2000

83. Pichard C, Gerber S, Laloi M, et al: Pituitary carcinoma: report of an exceptional case and review of the literature. J Endocrinol Invest 25:65-72, 2002

84. Plangger CA, Twerdy K, Grunert V, et al: Subarachnoid metastases from a prolactinoma. Neurochirurgia 28:235-237, 1985

85. Popadic A, Witzmann A, Buchfelder M, et al: Malignant prolactinoma: case report and review of the literature. Surg Neurol 51:47-55, 1999

86. Popovic EA, Vattuone JR, Siu KH, et al: Malignant prolactinomas. Neurosurgery 29:127-130, 1991

87. Queiroz Lde S, Facure NO, Facure JJ, et al: Pituitary carcinoma with liver metastases and Cushing syndrome. Report of a case. Arch Pathol 99:32-35, 1975

88. Rickert CH, Scheithauer BW, Paulus W: Chromosomal aberrations in pituitary carcinoma metastases. Acta Neuropathol 102:117-120, 2001

89. Rockwell BH, Pica R, Raji MR, et al: Intrathecal metastatic pituitary prolactinoma. AJR 167:1295-1296, 1996

90. Roncaroli F, Nose V, Scheithauer BW, et al: Gonadotropic pituitary carcinoma: HER-2/neu expression and gene amplification. Report of two cases. J Neurosurg 99:402-408, 2003

91. Roncaroli F, Scheithauer BW, Young WF, et al: Silent croticotroph carcinoma of the adenohypophysis: a report of five cases. Am J Surg Pathol 27:477-486, 2003

92. Saeger W, Bosse U, Pfingst E, et al: [Prolactin producing hypophyseal carcinoma. Case report of an extremely rare metastatic tumor.] Pathologe 16:354-358, 1995 (Ger)

93. Sakamoto T, Itoh Y, Fushimi S, et al: Primary pituitary carcinoma with spinal cord metastasis-case report. Neurol Med Chir 30:763-767, 1990

94. Salassa RM, Kearns TP, Kernohan JW, et al: Pituitary tumors in patients with Cushing's syndrome. J Clin Endocrinol Metab 19:1523-1539, 1959

95. Scheithauer BW, Fereidooni F, Horvath E, et al: Pituitary carcinoma: an ultrastructural study of eleven cases. Ultrastruct Pathol 25:227-242, 2001

96. Scheithauer BW, Horvath E, Kovacs K, et al: Prolactin-producing pituitary adenoma and carcinoma with neuronal components-a metaplastic lesion. Pituitary 1:197-205, 1999

97. Scheithauer BW, Jaap AJ, Horvath E, et al: Clinically silent corticotroph tumors of the pituitary gland. Neurosurgery 47: 723-730, 2000

98. Scheithauer BW, Randall RV, Laws ER Jr, et al: Prolactin cell carcinoma of the pituitary. Clinicopathologic, immunohistochemical, and ultrastructural study of a case with cranial and extracranial metastases. Cancer 55:598-604, 1985

99. Scholz DA, Gastineau CF, Harrison EG Jr: Cushing's syndrome with malignant chromophobe tumor of the pituitary and extracranial metastasis. Report of a case. Mayo Clin Proc 37: $31-42,1962$

100. Sheldon WH, Golden A, Bondy PK: Cushing's syndrome produced by a pituitary basophil carcinoma with hepatic metastases. Am J Med 17:134-142, 1954

101. Shibuya M, Saito F, Miwa T, et al: Histochemical study of 


\section{Pituitary carcinoma}

pituitary adenomas with Ki-67 and anti-DNA polymerase alpha monoclonal antibodies, bromodeoxyuridine labeling, and nucleolar organizer region counts. Acta Neuropathol 84: 178-183, 1992

102. Singh G, Pais P, Garg I: Refractory hypokalemia in metastatic adrenocorticotrophic hormone-secreting pituitary carcinoma. J Assoc Physicians India 48:448-449, 2000

103. Sironi M, Cenacchi G, Cozzi L, et al: Progression on metastatic neuroendocrine carcinoma from a recurrent prolactinoma: a case report. J Clin Pathol 55:148-151, 2002

104. Solitare GB, Jatlow P: Adenohypophysial carcinoma. Case report. J Neurosurg 26:624-632, 1967

105. Spertini F, Deruaz JP, Perentes E, et al: Luteinizing hormone (LH) and prolactin-releasing pituitary tumor: possible malignant transformation of the LH cell line. J Clin Endocrinol Metab 62:849-854, 1986

106. Stewart PM, Carey MP, Graham CT, et al: Growth hormone secreting pituitary carcinoma: a case report and literature review. Clin Endocrinol 37:189-194, 1992

107. Suzuki K, Morii K, Nakamura J, et al: Adrenocorticotropinproducing pituitary carcinoma with metastasis to the liver in a patient with Cushing's disease. Endocr J 49:153-158, 2002

108. Taylor WA, Uttley D, Wilkins PR: Multiple dural metastases from a pituitary adenoma. Case report. J Neurosurg 81: 624-626, 1994

109. Thapar K, Kovacs K, Scheithauer BW, et al: Proliferative activity and invasiveness among pituitary adenomas and carcinomas: an analysis using the MIB-1 antibody. Neurosurgery 38: 99-107, 1996

110. Thapar K, Scheithauer BW, Kovacs K, et al: p53 expression in pituitary adenomas and carcinomas: correlation with invasiveness and tumor growth fractions. Neurosurgery 38:763-771, 1996

111. Tonner D, Belding $\mathrm{P}$, Moore SA, et al: Intracranial dissemination of an ACTH secreting pituitary neoplasm - a case report and review of the literature. J Endocrinol Invest 15:387-391, 1992

112. Trainer PJ, Besser GM (eds): The Bart's Endocrine Protocols. Edinburgh: Churchill Livingstone, 1995

113. U SH, Johnson C: Metastatic prolactin-secreting pituitary adenoma. Hum Pathol 15:94-96, 1984
114. Vaquero J, Herrero J, Cincu R: Late development of frontal prolactinoma after resection of pituitary tumor. J Neurooncol 64:255-258, 2003

115. Vidal S, Kovacs K, Horvath E, et al: Microvessel density in pituitary adenomas and carcinomas. Virchows Arch 438: 595-602, 2001

116. von Werder K, Landgraf R, Oeckler R, et al: Treatment of prolactinomas, in del Pozo E, Flückiger E (eds): Dopamine and Neuroendocrine Active Substances. New York: Academic Press, 1985, pp 73-82

117. Walker JD, Grossman A, Anderson JV, et al: Malignant prolactinoma with extracranial metastases: a report of three cases. Clin Endocrinol 38:411-419, 1993

118. Williams BO, Schmitt EM, Remington L, et al: Extensive contribution of Rb-deficient cells to adult chimeric mice with limited histopathological consequences. Embo J 13:4251-4259, 1994

119. Winkelmann J, Pagotto U, Theodoropoulou M, et al: Retention of dopamine 2 receptor mRNA and absence of the protein in craniospinal and extracranial metastasis of a malignant prolactinoma: a case report. Eur J Endocrinol 146:81-88, 2002

120. Young WF Jr, Scheithauer BW, Kovacs KT, et al: Gonadotroph adenoma of the pituitary gland: a clinicopathologic analysis of 100 cases. Mayo Clin Proc 71:649-656, 1996

121. Zafar MS, Mellinger RC, Chason JL: Cushing's disease due to pituitary carcinoma. Henry Ford Hosp Med J 32:61-66, 1984

122. Zahedi A, Booth GL, Smyth HS, et al: Distinct clonal composition of primary and metastatic adrencorticotrophic hormoneproducing pituitary carcinoma. Clin Endocrinol 55:549-556, 2001

Manuscript received February 19, 2004.

Accepted in final form March 2, 2004.

Address reprint requests to: William T. Couldwell, M.D., Ph.D., Department of Neurosurgery, University of Utah School of Medicine, 30 N 1900 E, Suite 3B409 Salt Lake City, Utah 84132. email: william.couldwell@hsc.utah.edu. 